Article

\title{
Gender, Intra-Household Discrimination and Cash Transfer Schemes: The Case of Indian Punjab
}

\author{
Nadia Singh
}

Newcastle Business School, Northumbria University, Newcastle NE1 8ST, UK; nadia.singh@northumbria.ac.uk

Received: 24 May 2019; Accepted: 17 July 2019; Published: 19 July 2019

\begin{abstract}
For many years, the Punjab province of India has had the dubious distinction of having the worst sex ratio among all other states of India. In recent years, both the child sex ratio and the overall sex ratio has shown a marked improvement in the state. This paper analyses whether the improvement in sex ratios has narrowed down gender discrimination against the girl child in Punjab. This paper examines the intra-household gender differences in indicators of nutrition and well-being by employing logistic regression analysis on the latest available data from the National Family Health Survey (NFHS) for the year 2015-2016. It also evaluates the cash transfer schemes currently being implemented in Punjab for the welfare of the girl child and analyses their relative efficacy. The key results from the study reveal that gender continues to have a significant impact on indicators of child well-being and nutrition such as the average duration of breastfeeding and intra-household food allocation. The paper also finds that cash transfer schemes do not have a statistically significant impact on indicators of child malnutrition in the state.
\end{abstract}

Keywords: gender discrimination; sex ratios; health care; nutrition; well-being; cash transfers

JEL Classification: D1; D13; D61

\section{Introduction}

Gender inequality is deeply engrained in the fabric of many regions of the developing world. The most noted manifestation of gender inequity is the abysmally low sex ratio across many regions of the developing world. Sen (1990) conceptualized this as "missing women" 1 or the additional number of women who would have been alive, had they been treated on a par with men. He compared the actual sex ratios in many developing countries with the expected sex ratios that would have prevailed had there been equal treatment of men and women in society. His estimates showed that the number of missing women in the world was close to 100 million.

Some scholars contend that low child sex ratios indicate that there is a higher risk of mortality among young girls in the age group of $0-4$ years (Arokiasamy 2002). The under- 5 mortality ratio in India was estimated at 108.5 female deaths for every 100 male deaths (Jamison et al. 2013). Also, during the past four decades, the decline in the Infant Mortality Rate (IMR) has been greater in boys than in girls, indicating that there is a survival bias against the girl child (Shrinivasan 2012). Most scholars agree that there are stark differences in male-female survival rates in India. However, the reasons for the low survival rate of girls, as compared to boys, are not clear. Some scholars argue that there

1 Sen's methodology was later refined by Coale (1991). He argued that Sen had compared the sex ratios in Asian countries with those of the developed nations of Europe and North America. However, Coale considered this unfair as these regions had very high sex ratios as a result of high levels of male mortality in the past wars. Coale refined Sen's calculations and concluded that the number of "missing women" is 60 million and not 100 million as suggested by Sen (Coale 1991, p. 522). 
is bias against the girl child in indicators of care and attention, which manifest themselves in high mortality rates for girls (Rosenzweig and Schultz 1982; Hill and Upchurch 1995; Pandey et al. 2002; Dasgupta et al. 2009; Singh and Singh 2015). Dasgupta et al. (2009) has classified gender bias against the girl child into three categories: Active bias (e.g., intentionally not taking a girl child to school); passive bias (e.g., taking longer to realize that a girl is sick than would be the case for a boy) and selective favouritism (choices made by resource constrained families that favour boys over girls).

Other scholars, however, find no evidence of such forms of discrimination against girls. Deaton (2003) found no differences in vaccination rates of girls and boys on the basis of District Health Survey data collected from seven developing countries. Duflo $(2005$, p. 113) has stated in this regard "Even in countries where preference for boys is strongest, there is no evidence that girls are discriminated against in normal circumstances." Marcoux (2002) conducted an extensive study on the basis of survey data collected from six developing countries, traditionally known for high levels of gender discrimination, between 1985 and 1997. His findings revealed that gender discrimination in nutritional status and anthropometric indicators has systematically disappeared over time. Similarly, Sommerfelt and Arnold (1998, p. 152) argued that the extent of intra household discrimination against the girl child is so small that it does not reveal itself in large-scale household survey data. Other studies have concluded that in India and other parts of South Asia, there is evidence of discrimination in medical care and expenditure but not in the allocation of food (Makinson 1994; Ueyuma 2007; Sharma 2014). Thus, one can conclude that in the existing body of literature there remains contention over the extent of gender bias against the girl child in terms of the allocation of resources, medical expenditure and food expenditure within the household.

It is against this background that this paper attempts to analyze whether there has indeed been an improvement in the status of the girl child in Indian Punjab at the intra-household level. The paper examines the intra-household discrimination against the girl child (age group of 6-59 months) in Punjab in two key dimensions: (a) breastfeeding practices (b) food allocation at the household level and hypothesizes:

Hypothesis 1 (H1). Young girls in the age group of 6-59 months are breastfed for a shorter duration as compared to boys.

Hypothesis 2 (H2). Young girls in the age group of 6-59 months have lower food allocations as compared to boys.

The next part of the paper evaluates the efficacy of cash transfer schemes in bringing about improvement in nutritional indicators of girl children and further hypothesizes.

Hypothesis 3 (H3). Girl children who are beneficiaries of cash transfer schemes have better nutritional indicators as compared to non-beneficiaries.

The remainder of the paper is divided into the following sections. Section 2 presents the background of gender discrimination in the case study region, Punjab, India. Section 3 presents the data sources used in the study. Section 4 lays down the methodological framework of the study. Section 5 presents the key findings from the research and discusses them in the context of the literature. Section 6 concludes.

\section{Gender Discrimination in Punjab}

Punjab is viewed by many academic scholars and most policymakers in India as one of the most developed states in India due to its relatively high levels of per capita income, developed infrastructure and low levels of poverty in comparison with other Indian states (Singh and Singh 2017; N. Singh 2017). However, this "development" co-exists with a highly patriarchal social structure and culture wherein the bias against girls and women is persistent (R. Kaur 2013). Punjab ranks fifth in terms of human development and sixth in terms of overall development when compared with other Indian states but 
this rank falls to 19th on the gender development index (UNFPA 2014) ${ }^{2}$. Sixteen per cent of girls in the state are missing at birth (UNFPA 2014). ${ }^{3}$ Both the child sex ratio and the over-all sex ratio in Punjab are among the lowest compared to all other major states of India (Census of India 2001, 2011).

Gender discrimination, neglect of the girl child and high degree of preference for sons are a pervasive reality in Punjabi society (Purewal 2010). In literature, there are three main reasons cited for the high degree of son preference in the Indian sub-continent. Firstly, sons are culturally regarded as the "keeper of the family name". Hence, the presence of male progeny ensures that the family name would continue (Robitaille 2012). Secondly, the presence of a male child ensures a higher position for women in the household. Sons are also considered more useful than daughters in times of financial stress and a security against destitution in old age ${ }^{4}$ (Dasgupta 1987). Thirdly, even though the practice of dowry was prohibited by law in India as far back as 1961, to date, it continues in practice. Bloch et al. (2004) empirically estimated that the average transfers from the bride's family to the groom's family is six times their annual salary. Due to the continuing practice of dowry, daughters are considered a drain on their family's resources.

Miller (1981, p. 20) first empirically documented this phenomenon in her anthropological study of several states of North India, including Punjab. She states, "The preference for sons in Punjab is so strong that daughters must suffer in order that the family's personal and culturally mandated needs remain fulfilled". Cowan and Dhanoa (1983) conducted a field survey in the Ludhiana district of Punjab and found that there were pronounced differences in the mortality and nutritional status of young boys and girls. She discovered that such differences were most pronounced among wealthy landed peasants, although they exist among the poor landless peasants as well. Some studies have found that the existing gender vulnerabilities in Punjab were exacerbated by the Green Revolution model of agricultural development in Punjab. On one hand, increased consumerism propagated the custom of dowry in Punjabi society (M. Kaur 2010, p. 43). On the other hand, new technology replaced the traditional labour that women contributed to in agriculture. With increased incomes, large land holding families began to confine women to the household, as a sign of their improved social standing (M. Kaur 2010, p. 44). This is evident from the fact that by the 1980s, the unemployment level among rural women in Punjab was 7.4 per cent, while in India as a whole, the level of unemployment among rural women stood at only 3.5 per cent ${ }^{5}$ (S. Singh 2000, p. 18).

In recent years, many studies reflect on the fact that even after decades of high economic growth, there has been little shift in the perception of people towards girls and women in society. Rapid economic growth and increasing literacy levels have led to smaller family sizes, decreasing fertility levels and late marriage, yet the desire for male progeny continues unabated in Punjabi families. Patel (2007) and Bose (2007) conducted two extensive studies in North India. Both these studies show that the "son complex" is deeply engrained in Punjabi society. The status and position of women in society is intricately linked to the birth of a son. In most parts of the state, although people now prefer to have smaller families, the preference for sons continues unabated. In an extensive study conducted across districts with the worst sex ratios in Punjab, Himachal Pradesh, Haryana, Rajasthan and Madhya Pradesh, John et al. (2008) find similar results. In Punjab, the study was conducted in the Fatehgarh Sahib district. This study reported that for most respondents in the region, the desired family composition comprised of one son and one daughter. The study also reported that the prevalence of sex-selective female abortions was inherently linked to desired family composition. If the first child is

2 The GDI measures the gender gaps in human development achievements by accounting for disparities between women and men in three dimensions: health, knowledge and living standards.

3 UNFPA stands for United Nations Population Fund.

4 Calculations have been made by the author on the basis of National Sample Survey Organisation Employment/Unemployment Data (1979-1980).

5 Kynch and Sen (1983) in a study based on admissions data from two large public hospitals in Mumbai, found it very striking that there was clear evidence that the admitted girls were typically more ill than boys, suggesting the inference that a girl has to be more stricken before she is taken to the hospital (see also Sen 2001). 
a boy, then most people do not opt for sex selection, as the gender of the second child does not matter much. However, if the first-born is a girl, the practice of sex-selective abortion gains momentum for the second child.

As far as gender discrimination regarding the care, attention and well-being of girls in Punjab is concerned, the evidence is mixed, similar to the trend in other regions of the world exhibiting son preference. Dasgupta (1987) conducted an extensive study on gender discrimination at the household level in the state on the basis of an extensive survey of 400 households in the Ludhiana district of Punjab. Her study found that girls received less care and attention at home, as compared to a boy child. "A girl child is less warmly clad, she is not so well fed as a boy and when ill, her parents are not likely to make the same effort as in the case of a son to ensure her treatment" (Dasgupta 1987, p. 75)

Years later, the picture remains unchanged as a number of other studies have also reported high levels of male bias in the provision of health care, nutrition, education and resource allocation in most parts of North India, especially Punjab and Haryana (Chaturvedi et al. 1996; Asfaw et al. 2007; UNICEF 2011; Tiwari 2013; Sharma 2014). These studies suggest that the root cause of such forms of discrimination is the patriarchal, intra-familial family structure of Punjab where the economic, religious and cultural utility of girls is perceived to be less than that of boys. However, Levinson et al. (2003) presented a more nuanced picture showing evidence of a decline in difference in gender mortality in early years. Their results are based on two studies conducted across 18 villages in the Morinda district of Punjab-one in 1971 and the other, in 2001. They report that while the mortality difference between boys and girls (in the age group of 0-3 years) was as high as 85 per cent in 1971, it had narrowed down to merely 13-14 per cent in 2001. This decline in mortality differences was observed across caste groups. They attribute this decline to economic prosperity and smaller-sized families. These factors also contribute to better care and attention being provided to female children in the family. John et al. (2008) report that gender differences in mortality were largely due to the practice of female feticide and sex-selective abortions. They do not find any evidence of discrimination against the girl child in the provision of healthcare and nutrition. On the other hand, Singh and Singh (2015) constructed a multivariate index and examined gender discrimination against the girl child in Punjab in indicators of childcare, nutrition and mortality on the basis of National Family Health Survey Data (NFHS-3 2005-06). They found that in many dimensions of childcare and well-being such as immunization coverage, treatment for common childhood illnesses and nutritional indicators, there is a pronounced bias against the girl child and this bias has worsened over time.

In recent years, the relative position of the girl child in the state seems to have improved to a certain extent, as indicated by both the overall sex ratio and child sex ratio. While the overall sex ratio has risen from 874/1000 in 2001 to $893 / 1000$ in 2011, registering an increase of 19 points, the child sex ratio has improved by 48 points from 798/1000 to 846/1000. Punjab has registered the most rapid improvement in the child sex ratio among all states of India. The state government claims that this improvement signifies a substantial decline in the degree of son preference in the state as a result of positive interventions by the government, strict enforcement of the Pre Natal Diagnostic Test (PNDT) Act and numerous cash transfer schemes initiated to promote the interest of the girl child in the state.

\section{Data Sources}

The present study makes use of data from the National Family Health Survey, NFHS-4 (2015-16). This is a nationally representative survey conducted by the Ministry of Health and Family Welfare, Government of India. NFHS-4 fieldwork for Punjab was conducted in all 20 districts of the state and collected information from 19,484 women aged 15-49 and 3250 men aged 15-54 through detailed questionnaires. Four types of questionnaires were administered in this survey-household, men, women and biomarker. The household questionnaire collected information on the total members of

6 Health status is estimated on the basis of prevalence of anaemia in the last 12 months. 
the household, socio-economic characteristics of the household, water, sanitation, health insurance and number of deaths in the family in the preceding three years. The women's questionnaire collected information on women's characteristics, marriage, fertility, contraception, reproductive health, children's immunizations, and treatment of childhood illnesses The men's questionnaire covered the man's characteristics, marriage, number of children, contraception, fertility preferences, nutrition, sexual behaviour, attitudes towards gender roles, HIV/AIDS, and lifestyle. The biomarker questionnaire covered measurements of height, weight, and hemoglobin levels for children; height, weight, hemoglobin, blood pressure, and random blood glucose for women aged 15-49 years. The questionnaires were administered with the informed consent of the participants. Survey response rates were 99 percent for households, 98 percent for women, and 93 percent for men.

The NHS-4 survey contains detailed information on breastfeeding practices, food intake and anthropometric measures of children. Information on breastfeeding outcomes included three measures of compliance with the World Health Organisation (WHO)-recommended breastfeeding practices-the initiation of breastfeeding, the duration of breastfeeding and the introduction of complementary, solid, semi-solid and soft foods at the age of six months. Food intake was measured using the mother's report on whether and how frequently the child received milk, eggs, fruits, vegetables and other specific foodstuffs. Data on anthropometric measures comprised of weight for age $\mathrm{Z}$ score, height for age $\mathrm{Z}$ score and weight for height $Z$ score with respect to the WHO reference population.

The descriptive statistics for the sample studied are summarized in Table 1 below, these are disaggregated by gender.

Table 1. Descriptive Statistics for the sample population, NFHS-4, children in the age group of 6-59 months.

\begin{tabular}{ccccc}
\hline \multicolumn{2}{c}{ Females } & \multicolumn{3}{c}{ Males } \\
\hline Variable & Mean Value & St. Dev & Mean & St Dev \\
\hline Child's age (months) & 25.2 & 16.24 & 26.3 & 17.18 \\
\hline Mother's age (years) & 24.9 & 3.1 & 23.5 & 4.09 \\
\hline Mother's Education & - & - & - & - \\
\hline No schooling & $6.10 \%$ & 0.09 & $6.30 \%$ & 0.44 \\
\hline Primary School & $14.70 \%$ & 0.87 & $15.68 \%$ & 0.92 \\
\hline Secondary School & $58.90 \%$ & 0.5 & $60.20 \%$ & 0.4 \\
\hline Higher Education & $14.20 \%$ & 0.03 & $16.30 \%$ & 0.02 \\
\hline Wealth Index of Household & - & - & - & - \\
\hline Deprived & $11.90 \%$ & 0.02 & $11.70 \%$ & 0.84 \\
\hline Middle Income & $61.40 \%$ & 0.89 & $62.60 \%$ & 0.98 \\
\hline Higher Income & $16.23 \%$ & 0.45 & $14.90 \%$ & 0.42 \\
\hline
\end{tabular}

Source: Unit record data of NFHS-4 (2015-16). Notes: 1. These statistics are based on information collected from women in the NFHS survey. 2. Households with a monthly income of less than Rupees 7500 per month are categorized as "deprived" households; households with a monthly income between Rupees 7500 and Rupees 20,000 per month are categorized as "middle-income" households. Households with a monthly income of more than Rupees 20,000 per month are categorized as "higher-income" households.

\section{Methodology}

The paper employs multivariate logistic regression model in order to analyse the gender disparities in breastfeeding and food allocation among girls and boys in Punjab. We adopted the analytical model specified by Fledderjohann et al. (2014). The model specifications are explained below:

Nutrition $_{i j}=a+B_{\text {Female } i, j}+B_{\text {child age } i, j}+B_{\text {maternal age } i, j}+B_{\text {maternal education } i, j}+B_{\text {household } i, j}+u_{i j}+e_{i j}$ 
Here, $i$ stands for the child and $\mathrm{j}$ stands for the mother. The dummy variable for a child's gender is female ( $1=$ female, $0=$ Male). A child's age is measured in months. A mother's age is measured in years. A mother's education is a categorical variable which is divided into 4 categories: no schooling, primary schooling, secondary schooling and higher education. Household characteristics include the wealth index of the household. This is divided into three categories: deprived, middle-income households and higher income households. $U$ is the mother's fixed effects. e is the error term.

The nutritional status of the child is estimated using two dimensions, breastfeeding practices and food intake. In order to measure gender discrimination in breastfeeding practices, we used World Health Organisation (WHO)-recommended guidelines as the reference (WHO 2003). We measured the extent of discrimination along the following four dimensions: initiation of breastfeeding (which should be within one hour of birth); duration of breastfeeding and the practice of exclusive breastfeeding for the first six months of the child's life. These dimensions were based on the mother's responses to a series of questions about breastfeeding practices. Food intake was measured using the mother's report of whether and how frequently the child received milk, eggs, meat, fruits and vegetables, and other specified food items in the $24 \mathrm{~h}$ preceding the survey.

The second part of the paper evaluates the impact of cash transfer schemes on the nutritional status of girl children. The study hypothesizes that everything else being equal, girl children who are beneficiaries of cash transfer schemes have better health and nutritional outcomes as compared to non-beneficiaries. The hypothesis was tested using three anthropometric measures of child malnutrition-stunting, wasting and being underweight. The paper employs the analytical model specified by Alderman et al. (2006) specified as:

\section{Nutritional status $=F(C i, P i, H i, U i, T)$}

Nutritional status of the child is a function of:

Child's characteristics (Ci): Age of the child, health status in the previous period.

Parent's characteristics (Pi): Education of the parents.

Household characteristics (Hi): Wealth index of the household, caste, and number of children in the house.

Community characteristics (Ui): Whether burning biomass as the main source of fuel.

Treatment effect $(T)$ : Whether the girl children were beneficiaries of a cash transfer scheme.

The data set used for this analysis comprised of a total of 628 children, under the age of 6 years This consisted of 380 girls and 248 boys.

I ran an ordinary least squares (OLS) regression on three nutritional status outcomes-weight-for-age, weight-for-height and height-for-age z-scores. These variables measure the extent to which a child is underweight, wasted or stunted with respect to the WHO reference scores. The main independent variable in the model is whether any girl child/children in the household received cash transfers from the government in the past 12 months. The main dependent variables in this model comprised of child-specific characteristics (age and health status of the child ${ }^{7}$ ), parent-specific characteristics (highest year of schooling of mother and father). The household characteristics included wealth index of the household ${ }^{8}$, caste, and number of children in the household. The community characteristics include whether the household burns biomass as the main fuel at home. Biomass burning remains a major socio-economic concern in Punjab. Close to 51.2 percent of the households in rural Punjab continue to depend on traditional biomass energy, and do not have access to "clean" energy sources (NFHS-4 2015-16). This is associated with severe health ramifications, especially for young girls and women in the household (N. Singh 2017).

7 We adopted the standard NFHS classification and categorized households as deprived households, middle-income households and higher income households.

8 Fertility rate in Punjab (1.6) is below the replacement ratio of 2.1 children born per women (NFHS-4 2015-16). 


\section{Key Findings}

\subsection{Gender Bias in Breastfeeding Practices}

Table 2 below shows the results of the multivariate logistic regression model and tests for the odds of adhering to the WHO best-practice norms, regarding initiation of breastfeeding, exclusive breastfeeding for 6 months and the duration of breastfeeding practice. In this model, other factors such as the mother's age, mother's highest education level and deprivation of the household are assumed to be constant. After accounting for these differences, I found that there is a significant gender bias in the average duration of breastfeeding between boys and girls in Punjab. On average, girl children are breastfed 0.45 months less than boys. However, I did not find evidence of any gender discrimination in the initiation of breastfeeding and the prevalence of exclusive breastfeeding in the first six months.

These results are in consonance with other studies as well. Across many areas of the world with a high degree of son preference, there is a pronounced gender bias in the duration of breastfeeding (Young Lives 2012). Some scholars attribute it to the desire to invest more in son's health as compared to a daughter's health (Mishra 2004; Jayachandra and Kuziemko 2010). Other authors argue that many parents desire to have fewer children after a son is born. However, after the birth of a daughter, most parents desire to have another child soon afterwards. As a result, girls are breastfed for shorter time periods, less frequently and for shorter durations than male infants (Arokiasamy 2003; Tiwari 2013). Previous studies have shown that gender discrimination in breastfeeding duration account for a significant proportion of poorer survival outcomes among girls, as compared to boys (Huffman and Lamphere 1984; Bhutta et al. 2008). Habicht et al. (1986) estimated that each additional month of breastfeeding reduced infant death by 6 per thousand live births. These results were also confirmed by Fledderjohann et al. (2014).

Table 2. Gender bias in breastfeeding practices, children aged 6-59 months.

\begin{tabular}{ccccccc}
\hline Variable & OR & $\mathbf{9 5 \% ~ C I ~}$ & OR & $\mathbf{9 5 \% ~ C I ~}$ & OR & $\mathbf{9 5 \% ~ C I ~}$ \\
\hline Female & 1.11 & {$[0.97$ to 1.22$]$} & 1.04 & {$[0.92$ to 1.10$]$} & $-0.45^{* *}$ & {$[-0.75$ to 0.15$]$} \\
\hline Age of the Child & 1 & {$[1.00$ to 1.01$]$} & $1.03^{* *}$ & {$[1.03$ to 1.03$]$} & $0.23^{* *}$ & {$[0.23$ to 0.25$]$} \\
\hline Mother's age & 1.03 & {$[1.02$ to 1.04$]$} & 1.01 & {$[0.99$ to 1.02$]$} & 0.01 & {$[0.06$ to 0.03$]$} \\
\hline $\begin{array}{c}\text { Mother's } \\
\text { highest Level of } \\
\text { Education }\end{array}$ & $1.83 *$ & {$[1.56$ to 2.15$]$} & 1.6 & {$[1.43$ to 1.77$]$} & $-0.82 * *$ & {$[0.36$ to 1.00$]$} \\
\hline $\begin{array}{c}\text { Deprived } \\
\text { Household }\end{array}$ & 1.08 & {$[0.98$ to 1.09$]$} & 1.05 & {$[0.95$ to 1.17$]$} & 0.98 & {$[1.43$ to 0.18$]$} \\
\hline $\begin{array}{c}\text { Mother's ID } \\
\text { (fixed effects) }\end{array}$ & $1 * * *$ & {$[1.00$ to 1.00$]$} & 1 & {$[1.00$ to 1.00$]$} & $1 * *$ & {$[1.000$ to 1.00$]$} \\
\hline R-squared & 0.03 & & 0.03 & & 0.01 & \\
\hline
\end{tabular}

Source: NFHS-4 (2015-16). Notes: ${ }^{*}$ indicates significance at $1 \%$ level, ${ }^{* *}$ indicates significance at $5 \%$ level, $* * *$ indicates significance at $10 \%$ level. Key: OR denotes the Odds Ratio, CI denotes the Confidence Interval, Sample Size $(\mathrm{N})=4811$.

Thus, from the above analysis, one can conclude that hypothesis 1 is supported by data and there is a statistically significant bias against the girl child in Punjab in terms of median duration of breastfeeding. However, on the positive side, there is no evidence of gender bias in terms of the practice of exclusive breastfeeding for the first six month's of an infant's life and the initiation of breastfeeding (one hour after birth).

\subsection{Gender Bias in Food Allocation}

In Table 3 below, I employ logistic regression analysis and test the odds of girl children in the age group of 6-59 months receiving the same food allocations as compared to boys within the household. 
The analysis reveals that girl children have lower odds of receiving fresh milk [OR $=0.84,95 \% \mathrm{CI} 0.75$ to 0.92 ], chicken and other poultry products [OR $=0.78,95 \% \mathrm{CI} 0.70$ to 0.90 ] as well as eggs [OR $=0.86$, $95 \%$ CI 0.78 to 0.94 ]. I did not find evidence of gender discrimination in the consumption of any other food items among boys and girls in Punjab in the age group of 6-59 months.

Table 3. Odds ratio of consumption of specific food items for females compared with males, aged 6-59 months.

\begin{tabular}{ccc}
\hline Food Item & OR & 95\% CI \\
\hline Fresh Milk & $0.84^{* * *}$ & {$[0.75$ to 0.92] } \\
\hline Chicken, duck and any other poultry products & $0.78^{* *}$ & {$[0.70$ to 0.90] } \\
\hline Any other meat & 0.99 & {$[0.87$ to 1.22$]$} \\
\hline Lentils & 1.02 & {$[0.88$ to 1.15] } \\
\hline Nuts & 0.99 & {$[0.64$ to 1.25$]$} \\
\hline Eggs & $0.86^{* *}$ & {$[0.78$ to 0.94$]$} \\
\hline Fish & 0.87 & {$[0.80$ to 1.12$]$} \\
\hline Cheese, yoghurt and other dairy products & 0.96 & {$[0.90$ to 1.17$]$} \\
\hline Porridge & 1.07 & {$[0.98$ to 1.24$]$} \\
\hline Potato, cassava and other vegetables made from roots & 0.98 & {$[0.91$ to 1.12$]$} \\
\hline Pumpkin, carrot and squash & 1.03 & {$[0.93$ to 1.15$]$} \\
\hline Dark green leafy vegetables & 0.96 & {$[0.87$ to 1.12$]$} \\
\hline Mango, papaya and jackfruit & 0.99 & {$[0.89$ to 1.10$]$} \\
\hline Other fruits and vegetables & 0.96 & {$[0.84$ to 1.10] } \\
\hline Oil, fat and butter & 0.95 & {$[0.85$ to 1.11] } \\
\hline Other solid/semi-solid foods & 1.05 & {$[0.91$ to 1.12$]$} \\
\hline
\end{tabular}

Source: Unit record data of NFHS-4 (2015-16); Note: * indicates significance at 1\% level, ${ }^{* *}$ indicates significance at $5 \%$ level, ${ }^{* * *}$ indicates significance at $10 \%$ level; The model was adjusted for child's age (months), mother's age (years), household deprivation and mother's fixed effects; Key: OR denotes Odds Ratios, CI denotes confidence interval, Sample Size $(\mathrm{N})=4811$.

This analysis can also help to explain probable causation between gender bias in food intake and higher under-five mortality levels among girls as compared to boys in Punjab. A previous study, Singh and Singh (2015) estimated that the under-five mortality rate among girls is 58.9/1000 compared to only 51.3/1000 for boys. A number of authors have highlighted that higher levels of child mortality among girls are an indicator of lower household investment in the girl child (Miller 1981; Rosenzweig and Schultz 1982; D'Souza 2005). From this analysis, one may conclude that in the case of Punjab, higher under-five mortality rates among young girls may be correlated with discrimination in food allocation of high-protein food items such as milk, eggs and chicken. Fledderjohann et al. (2014) used a similar methodology and employed NFHS-3 data (2006-06) in order to measure gender bias in food intake for India as a whole. They found evidence of gender bias in terms of consumption of fresh milk. But these authors did not find evidence of gender bias in consumption of any other food item. In another study, Mishra (2004) found evidence of gender discrimination in food allocation in both fresh milk and poultry and demonstrated that this discrimination manifests itself in the form of anthropometric indicators of girls. However, in a previous study, Basu (1989) concluded that the extent of gender discrimination in food allocation is insignificant at the all-India level and could not explain the gender differences in nutritional outcomes.

The analysis suffers from certain data limitations. Firstly, data on the quantity of food items in different categories has not been collected in the survey. Had this data been available, the analysis 
could have been richer. Secondly, the data on food intake is based on mothers' reporting. However, previous studies suggest that mothers often tend to underreport on the bias in food consumption between boys and girls (Chaturvedi et al. 1996; Dasgupta 1987; Pandey et al. 2002; Jayachandra and Kuziemko 2010; Zimmerman 2011). This phenomenon has been termed as "social desirability bias" by Fledderjohann et al. (2014). Due to these factors, the analysis may tend to underestimate the extent of gender bias in food allocations between young girls and boys in Punjab. Hence, more in-depth survey-based research is required in Punjab in order to look at these factors in greater detail.

\subsection{Efficacy of Cash Transfer Schemes in Bringing about Better Nutritional Outcomes among Girl Children}

In the final part of the analysis, I evaluated the efficacy of cash transfer schemes in bringing about equitable nutritional outcomes among young boys and girls in Punjab. It is argued that state policies can have an important role in curbing gender bias against the girl child (UNICEF 2011). When the state makes free provision of nutrition, healthcare and education, the need to ration scarce household goods among family members is lessened (Duflo 2005). This can, in turn, be an important contributing factor in ensuring better care and attention to girl children, especially those belonging to disadvantaged families.

In recent years, the government has launched a new policy initiative in the form of conditional cash transfer schemes (CCTs) to promote better care for and attention to the girl child. These schemes provide a set of financial incentives to poor families to encourage them to invest more in a girl child's health and nutritional outcomes (UNFPA 2014). These incentives are given to the family, provided that they provide evidence of registration of birth, complete immunization coverage, enrollment at school, and delaying the age of marriage until 18 years (Singh and Singh 2017). The ultimate objective of the schemes is to change attitudes towards girl children.

A number of studies in different parts of the developing world suggest that cash transfer schemes have a positive impact on health and nutrition outcomes of children belonging to resource-constrained families. Duflo (2003) conducted a seminal study on cash transfers in South Africa, and found that cash transfers to grandmothers resulted in improved anthropometric indicators of granddaughters. Other studies have shown that cash transfers result in improved nutritional outcomes for children (Maluccio and Flores 2004; Haddad et al. 2003), as well as improvements in cognitive abilities and socio-emotional parameters of child development (Paxson and Schady 2010).

To date, there has been no systematic quantitative evaluation of the impact of cash transfer schemes in Punjab. In order to contribute to this critical area, we assessed the effectiveness of cash transfer schemes in improving nutrition indicators of girl children up to 6 years of age. The paper analyzes the effect of cash transfers by running an Ordinary Least Squares regression. Table 4 shows the effect of the scheme on the three nutritional indicators: weight-for-age z-scores (underweight), weight-for-height $\mathrm{z}$-scores (wasting) and height-for-age z-scores (stunting). Evidence from this analysis does not support the underlying hypothesis that participation in cash transfer schemes reduces the incidence of child malnutrition among young girls in Punjab. Among the other variables included in the model, I found that the previous health status of the girl child had a negative impact on the weight-for-age $\mathrm{z}$-score (being underweight). Among the parental characteristics, I found that mother's education levels had a positive impact on all three anthropometric measures for the girl child. I also found that the wealth index of the household had a positive impact on all three anthropometric measures for the girl child. On the other hand, traditional biomass burning in the household had a negative impact on weight-for-age z-scores (underweight) and height-for-age z-scores (stunting) of young girls.

The quantitative analysis reinforces findings from previous research in Punjab. Singh and Singh $(2015,2017)$ conducted qualitative evaluations of cash transfer schemes of the Punjab government. These studies found that cash transfer schemes have been very poorly designed and have had limited outreach so far. Most of the cash transfer schemes for the girl child have been implicitly related to population control, and require beneficiary mothers to undergo sterilization procedures. This is 
despite the fact that overpopulation is not a major problem in the state ${ }^{9}$ Intended beneficiaries are also required to meet with a number of other stringent and unreasonable conditions. For example, the intended beneficiaries are required to provide a number of documents such as birth certificate, income certificate, domicile certificate, bank statements and record of sterilization. This difficulty in assessing cash transfer schemes has undermined the outreach of these schemes. There are only 628 girl children in the state who are beneficiaries of cash transfers so far (NFHS-4 2015-16). Thus, due to the poor outreach and flawed design of these schemes, they have failed to have any significant positive impacts on the nutritional outcomes of girl children in the state.

Table 4. Regression results to estimate the impact of cash transfers on nutritional status of girls under the age of 6 .

\begin{tabular}{|c|c|c|c|}
\hline \multirow{2}{*}{ Variable } & Weight-for-Age z-Score & Weight-for-Height z-Score & Height-for-Age z-Score \\
\hline & (Underweight) & (Wasting) & (Stunting) \\
\hline $\begin{array}{l}\text { Beneficiary of cash } \\
\text { transfer scheme }\end{array}$ & $0.0132(0.001)$ & $\begin{array}{l}0.0032 \\
-0.006\end{array}$ & $\begin{array}{l}0.053 \\
-0.04\end{array}$ \\
\hline \multicolumn{4}{|c|}{ Child Specific Characteristics } \\
\hline Age of the Child & $\begin{array}{c}0.02 \\
-0.038 \\
\end{array}$ & $\begin{array}{l}0.039 \\
-0.07\end{array}$ & $0.024(0.029)$ \\
\hline $\begin{array}{l}\text { Health Status of the } \\
\text { Child }\end{array}$ & $\begin{array}{l}-0.232 * * \\
-0.01\end{array}$ & $\begin{array}{l}-0.181 \\
-0.002\end{array}$ & $\begin{array}{l}-0.085 \\
-0.09\end{array}$ \\
\hline \multicolumn{4}{|c|}{ Parent Specific Characteristics } \\
\hline \multirow[t]{2}{*}{$\begin{array}{l}\text { Highest Years of } \\
\text { Schooling (Mother) }\end{array}$} & $0.20 *$ & $0.29 * *$ & $0.018^{* *}$ \\
\hline & -0.08 & -0.06 & -0.06 \\
\hline \multirow[t]{2}{*}{$\begin{array}{l}\text { Highest Year of } \\
\text { Schooling (Father) }\end{array}$} & 0.45 & 0.76 & 0.21 \\
\hline & -0.01 & -0.01 & -0.01 \\
\hline \multicolumn{4}{|c|}{ Household Characteristics } \\
\hline \multirow[t]{2}{*}{ Wealth Index } & $0.47^{* *}$ & 0.93 & $0.63^{* *}$ \\
\hline & -0.01 & -0.001 & -0.01 \\
\hline \multirow[t]{2}{*}{$\begin{array}{l}\text { Number of Children in } \\
\text { the household }\end{array}$} & -0.85 & -0.73 & $-0.13(0.029)$ \\
\hline & -0.02 & -0.002 & \\
\hline \multirow[t]{2}{*}{$\begin{array}{l}\text { Whether burning } \\
\text { biomass at home }\end{array}$} & $-0.42^{* *}$ & -0.26 & $-0.35^{*}$ \\
\hline & -0.001 & -0.001 & -0.004 \\
\hline \multirow[t]{2}{*}{ Caste } & 0.1 & 0.14 & 0.05 \\
\hline & 0 & -0.036 & -0.001 \\
\hline R squared & 0.143 & 0.189 & 0.811 \\
\hline \multicolumn{4}{|c|}{ Source: Unit Record data of NFHS-4 (2015-16) } \\
\hline
\end{tabular}

Notes: * indicates significance at $1 \%$ level, ${ }^{* *}$ indicates significance at $5 \%$ level. The figures in parentheses indicate standard deviations. Key: Sample size $(n)=628$.

9 Culturally, it is considered inauspicious to accept gifts and financial aid from daughters in India. 


\section{Conclusions and Policy Recommendations}

The results of the analysis reveal that although Punjab has made remarkable progress in reversing the trend of declining overall sex ratio and the child sex ratio in the last few years, a lot could be done to further narrow down the gender differences in indicators of intra-household care and well-being.

The results of the regression analysis have reiterated the fact that gender has a significant impact on the duration of breastfeeding and intrahousehold food allocations, especially for high-protein foods such as chicken, eggs and milk. This discrimination in the early years of a girl child's life manifests itself in the form of higher under-five mortality levels for girl children in the state.

Policymakers in Punjab have attempted to correct the gender bias in indicators of household care and attention through a range of cash transfer schemes. However, the analysis reveals that so far, these schemes have failed to have a significant and positive impact on the nutritional status of girl children in the state. This may be partly attributed to the flawed design, and poor outreach of the schemes. I also found that the nutritional status of a girl child is significantly impacted by a number of factors such as household wealth, mother's education and incidence of biomass burning at home.

To conclude, the analysis demonstrates that gender disparity in nutrition and childcare is a complex socioeconomic phenomenon, very intimately connected to a household's social status and wealth, as well as maternal nutrition, education and empowerment. As an interim measure, provision of supplementary nutrition through cash transfers can help to alleviate short-term malnourishment and reduce intrahousehold inequities in food allocations, especially in the case of poor families. Even the existing cash transfer schemes for the girl child can also work, if modified, as a useful mechanism to encourage poor families to invest in the health and education of girls. However, from medium-term and long-term perspectives, a gender-aware mix of cultural initiatives, educational incentives, institutional and state-directed policy programmes including creation of employment opportunities for women and provision of "clean" energy sources at the household level are needed to grapple with the complexity of economic, social and cultural factors that influence the status and well-being of the girl child in Punjab.

Funding: This research received no external funding.

Conflicts of Interest: The author declares no conflict of interest.

\section{References}

Alderman, Harold, John Hoddinott, and Bill Kingsey. 2006. Long term consequences of Early Child Malnutrition. Oxford Economic Papers 58: 450-74. [CrossRef]

Arokiasamy, Perianayagam. 2002. Gender preference, contraceptive use and fertility in India: Regional and development influences. International Journal of Population Geography 8: 49-67. [CrossRef]

Arokiasamy, Perianayagam. 2003. Gender Preferences in Contraceptive use and fertility: Regional and Development Influences. International Journal of Population Geography 23: 66-75. [CrossRef]

Asfaw, Abay, Stephan Klassen, and Francesca Lamanna. 2007. Intra Household Disparities in Children's Medical Care before Death in India. IZA Discussion Papers No. 2586-2007. Available online: http://ftp.iza.org/dp2586.pdf (accessed on 12 February 2015).

Basu, Alaka M. 1989. Is discrimination in food really necessary for explaining sex differentials in childhood mortality? Population Study 43: 193-210. [CrossRef]

Bhutta, Zulfiqar A., Tahmeed Ahmed, Robert E. Black, Simon Cousens, and Kathryn Dewey. 2008. What works? Intervention for Child and Maternal Survival. The Lancet 371: 417-40. [CrossRef]

Bloch, Francis, Vijayendra Rao, and Sonalde Desai. 2004. Wedding celebrations as conspicuous consumption: Signalling social status in rural India. Journal of Human Resources 39: 675-95. [CrossRef]

Bose, Ashish. 2007. Female Foeticide: A Civilizational Collapse. In Sex Selective Abortions in India: Gender Society and New Reproductive Technologies. Edited by T. Patel. New Delhi: Sage Publications.

Census of India. 2001. General Population Tables and Primary Census Abstracts; Punjab Part 2A and Part 2 B. Series 12; New Delhi: Government of India. 
Census of India. 2011. General Population Tables and Primary Census Abstracts; Punjab Part 2A and Part 2 B. Series 17; New Delhi: Government of India.

Chaturvedi, Sanjay, Umesh M. Kapil, Nikesh Gnanasekaran, Harshpal S. Sachdev, Ravinder M. Pandey, and T. Bhanti. 1996. Nutrient intake amongst adolescent girls belonging to poor socioeconomic group of rural area of Rajasthan. Indian Pediatrics 33: 197-201.

Coale, Ansley J. 1991. Excess Female Mortality and the Balance of the Sexes in the Population: An Estimate of the Number of Missing Females. Population and Development Review 17: 517-23. [CrossRef]

Cowan, Betty, and Jasbir Dhanoa. 1983. The Prevention of Toddler Malnutrition by Home based Nutrition Education. In Nutrition in the Community: A Critical Look at Nutrition Policy and Programme. Edited by D. McLaren. New York: DS Mclern.

D'Souza, Stan. 2005. Sex differentials in mortality in early childhood. Population and Development Review 6: 257-70. [CrossRef]

Dasgupta, Monica. 1987. Selective Discrimination against Female Children in Rural Punjab, India. Population and Development Review 13: 77-100.

Dasgupta, Monica, Woojin Chung, and Li Shuzhuo. 2009. Is There an Incipient Turnaround in Asia's "Missing Girls" Phenomenon? In World Bank Policy Research Working Paper. Washington, DC: World Bank Publications, p. 4846.

Deaton, Angus. 2003. Health, Inequality, and Economic Development. Journal of Economic Literature 41: 113-58. [CrossRef]

Duflo, Esther. 2003. Grandmothers and Granddaughters: Old age pensions and intra-household Allocation in South Africa. World Bank Economic Review 17: 1-25. [CrossRef]

Duflo, Esther. 2005. Why Policy Reservations? Journal of Economic Perspectives 20: 112-34.

Fledderjohann, Jasmine, Sutapa Agrawal, Sukumar Vellakkal, Sanjay Basu, Oona Campbell, Pat Doyle, Shah Ebrahim and David Stucker. 2014. Do Girls Have a Nutritional Disadvantage Compared with Boys? Statistical Models of Breastfeeding and Food Consumption Inequalities among Indian Siblings. PLoS ONE 9: 17-24.

Habicht, Jean P., Julie Da Vanzo, and William P. Butz. 1986. Does breastfeeding really save lives, or are apparent benefits due to biases? American Journal of Epidermology 123: 279-90. [CrossRef]

Haddad, Lawrence, Harold Alderman, Simon Appleton, Lina Song, and Yisehac Yohannes. 2003. Reducing Child Malnutrition: How far does income growth take us? World Bank Economic Review 17: 107-31. [CrossRef]

Hill, Kenneth, and Dawn M. Upchurch. 1995. Gender differences in Child Health: Evidence from the Demographic and Health Surveys. Population and Development Review 21: 127-51. [CrossRef]

Huffman, Sandra L., and Barbara B. Lamphere. 1984. Breastfeeding performance and child survival. Population and Development Review 10: 93-116. [CrossRef]

Jamison, Dean T., Lawrence H. Summers, George Alleyne, Kenneth. J. Arrow, and Seth Berkley. 2013. Global health 2035: A world converging within a generation. The Lancet 38: 1898-955. [CrossRef]

Jayachandra, Seema, and Ilyana Kuziemko. 2010. Why do mothers breastfeed girls less than boys? Evidence and Implication for Child Health in India. The Quarterly Journal of Economics 126: 1485-538. [CrossRef]

John, Mary E., Ravinder Kaur, Rajni Palriwala, Saraswati Raju, and Alpana Sagar. 2008. Planning Families, Planning Gender: The Adverse Child Sex Ratios in Selected districts of Punjab, Haryana, Himachal Pradesh, Rajasthan and Madhya Pradesh. New Delhi: Books for Change.

Kaur, Mallika. 2010. The Paradox of India's Breadbasket: Farmer Suicides in Punjab. PRAXIS The Fletcher Journal of Human Security 25: 39-57.

Kaur, Ravinder. 2013. Mapping the adverse consequences of Sex Selection and Gender Imbalance in India and China. Economic and Political Weekly 48: 13-26.

Kynch, Jocelyn, and Amartya Sen. 1983. Indian women: Well being and survival. Cambridge Journal of Economics 7: 363-80. [CrossRef] [PubMed]

Levinson, James, Sucheta Mehra, Dorothy Lewis, Anita Kumari, Guy Koope, Brian Bence, and Astier M. Alemdom. 2003. Nutritional Well Being and Gender Differences: After 30 years of Rapid Growth in Rural Punjab. Economic and Political Weekly 38: 45-60.

Makinson, Carolyn. 1994. Discrimination against the female child. International Journal of Gynaecology E Obstetrics 46: 119-25.

Maluccio, John A., and Rafael Flores. 2004. Impact Evaluation of a Conditional Cash Transfer Program: The Nicaraguan Red de Protection Social. Washington, DC: International Food Policy Research Institute. 
Marcoux, Alain. 2002. Sex Differentials in Undernutrition: A Look at Survey Evidence. Population and Development Review 28: 275-84. [CrossRef]

Miller, Barbara D. 1981. The Endangered Sex: Neglect of Female Child in Rural North India. Itahaca: Cornell University Press. Mishra, Vinod. 2004. Sex Differentials in Childhood Feeding, Healthcare and Nutrition in India. Population and Development Review 30: 269-95. [CrossRef]

NFHS-3. 2005-06. National Family Health Survey. Mumbai: Ministry of Health and Family Welfare Government of India. NFHS-4. 2015-16. National Family Health Survey. Mumbai: Ministry of Health and Family Welfare Government of India. Pandey, Aparna, Priya G. Sengupta, Sabuz K. Mondal, Dhirendra N. Gupta, Byomkesh Manna, Subrata Ghosh, Dipika Sur, and Sujit K. Bhattacharya. 2002. Gender differences in healthcare-seeking during common illnesses in a rural community of West Bengal, India. Journal of Health, Population and Nutrition 20: 306-11.

Patel, Tulsi. 2007. Sex Selective Abortion in India: Gender, Society and New Reproductive Technologies. New Delhi: Sage Publications.

Paxson, Christina, and Norbert Schady. 2010. Does Money Matter? The Effect of Cash Transfers on Child Health and Development in Rural Ecuador. Economic Development and Cultural Change 59: 187-229. [CrossRef]

Purewal, Navtej K. 2010. Son Preference: Sex Selection, Gender and Culture in South Asia. London: Bloomsbury Publications.

Robitaille, Marie C. 2012. Determinants of Stated Son Preference in India: Are Men and Women Different? Journal of Developing Societies 49: 1-13. [CrossRef]

Rosenzweig, Mark, and Paul Schultz. 1982. Market Opportunities, Genetic Endowments, and Intrafamily Resource Distribution: Child survival in Rural India. The American Economic Review 72: 803-15.

Sen, Amartya. 1990. Inequalities, Women and World Development. New York: Oxford University Press.

Sen, Amartya. 2001. Many Faces of Gender Inequality. Frontline 18. Available online: http://www.frontline.in/ static/html/fl1822/18220040.htm (accessed on 3 July 2016).

Sharma, Kalpa. 2014. Will India Achieve Millennium Development Goals 4 and 5? In Regional Disparities and Social Development: Perspectives and Issues. New Delhi: Serials Publications.

Shrinivasan, Rukmini. 2012. India Deadliest Place in the World for the Girl Child. Times of India. Available online: https:/timesofindia.indiatimes.com/india/India-deadliest-place-in-world-for-girl-child/articleshow/ 11707102.cms (accessed on 14 February 2019).

Singh, Nadia. 2017. Sustainability Crisis: A Critical Evaluation of Green Energy Policies. Economic and Political Weekly 52: 66-69.

Singh, Sukhpal. 2000. Crisis in Punjab Agriculture. Economic and Political Weekly 35: 1889-92.

Singh, Pritam, and Nadia Singh. 2015. The Lesser Child: A Study of Inter-linkages between Child Sex Ratios and Discrimination against the Girl Child in Punjab. Journal of Punjab Studies 22: 287-317.

Singh, Pritam, and Nadia Singh. 2017. Confronting gender discrimination in Punjab: Evaluating cash transfer schemes. Economic and Political Weekly 52: 24-26.

Sommerfelt, Elizabeth A., and Fred Arnold. 1998. Sex differentials in nutritional status of young children. In Too Young to Die: Genes or Gender? New York: Population Division, United Nations, pp. 133-53.

Tiwari, Abhay Kumar. 2013. Gender Inequality in terms of health and nutrition in India: Evidence from NFHS-3. Pacific Business Review International 5: 24-34.

Ueyuma, Mika. 2007. Income Growth and Gender Bias in Childhood Mortality in Developing Countries. IFPRI Discussion Paper 00735. Washington, DC: IFPRI.

UNICEF. 2011. Strong Foundations: Early childhood care and education. In EFA Global Monitoring Report. Paris: UNICEF.

UNFPA. 2014. Sex Ratios and Gender Biased Sex Selection: History, Debates and Future Directions. Mumbai: International Institute of Population Science and UNFPA.

Young Lives. 2012. What Inequality Means for Children: Evidence from Young Lives. Oxford: Oxford University. WHO. 2003. Global Strategy for Infant and Young Child Feeding. Geneva: World Health Organization.

Zimmerman, Laura. 2011. Reconsidering Gender Bias in Intra Household Allocation in India. IZA Discussion Paper No. 5687. Available online: http://ftp.iza.org/dp5687.pdf (accessed on 12 March 2015).

(C) 2019 by the author. Licensee MDPI, Basel, Switzerland. This article is an open access article distributed under the terms and conditions of the Creative Commons Attribution (CC BY) license (http://creativecommons.org/licenses/by/4.0/). 